\title{
The Political Economy of Income Inequality in the United States
}

\author{
Kwan S. Kim
}

\section{Introduction}

The United States, in comparison to other industrialized democracies, has now a much larger segment of the working poor, and a relatively small segment of wealth-holding elite. In between are the middle Americans who enjoy varying degrees of relative affluence, which in recent years has, however, been diminishing in size in the context of increasing bipolarization of the society. The widening gap between rich and poor and the persistent poverty in the midst of affluence poses an enduring dilemma for American society.

The purpose of this paper is twofold: first to understand the levels of, and trends in, income inequality and poverty in the United States (Section 2) along with the factors contributing to the trends (Section 3), and secondly to explore the broad implications for America's social and political economy (Section 4). The main findings and policy implications are highlighted in the concluding section.

\section{American Income: Aggregate Trends}

Figure 1 shows trends in per capita real income over the period of 1967-1993, which is calculated as the inflation-adjusted sum of wages, rents, interest, profits and government transfers less taxes, and is used here as a broad gauge of economic well-being for Americans. Over the period per capita income grew at a $1.76 \%{ }^{1)}$ while estimates by Cox and $\mathrm{Fox}^{2)}$ for the earlier period from 1954 to 1973 show that it grew on average 2.1 $\%$ annually. During the 1950s and 1960s when the United States was a dominant economic power, the country had much higher growth rates, which slowed down in subsequent periods.

Aggregate statistics cited above reflect average numbers. Some have gained more, and others less. Figure 2 shows the trends in income inequality in America from 1978 to 1994 in terms of the gross household income which includes capital gains and the net household income that includes net transfer payments. In either of these measures, there was a rising trend in the Gini coefficient of income distribution over the period. After years of little change throughout the 1960s and the 1970s, inequality began to explode from the late 1970s on and especially after the initiation of supply-side economic policies under Reagan. During the 1980s more than three-quarters of income gains and almost entire wealth gains accrued to the top $20 \%$ of families ${ }^{3)}$. Correspondingly, the middle income jobs began to decline. The share of the jobs held by the middle Americans-defined as those earning between $50 \%$ and $150 \%$ of median level-fell from $75 \%$ in 1973 to $65 \%$ in $1985^{4)}$. The decline in the middle income share was offset by the increases in upper and lower income jobs.

Turning to the issue of poverty, the official poverty level defined by the US government is based on income before taxes. The poverty line was set initially in 1963 at the level three times the income needed to purchase the "Economy Food Plan," as designated by the Department of Agriculture. In subsequent years, it has been updated to correct for inflation. In 1993 the number of persons earning below the poverty level was 39.3 million, and as a percentage of the total population they accounted for $15.1 \%$, an increase from the 1992 figure of $14.8 \%$ and the 1989 rate of $13.1 \%$. From the historical perspective, the absolute number and the share of the poor 
Figure 1. Per Capita Real Income by Race \& Hispanic Origin

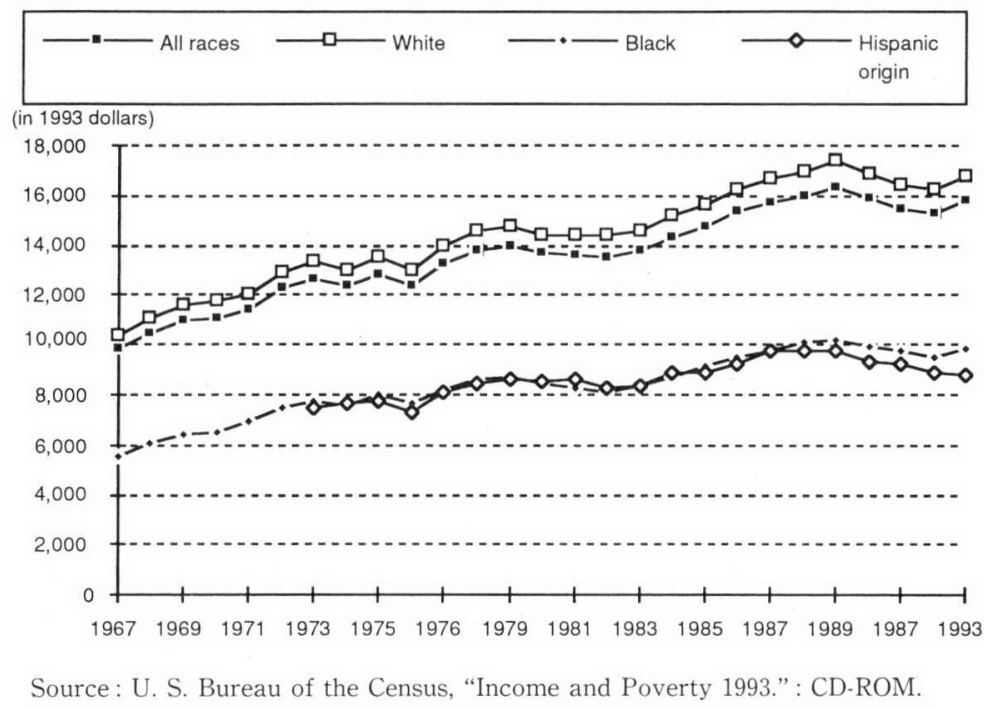

fell in the period preceding the mid-1970s and rose thereafter (Figure 3). While the earlier period saw heavy government involvements in social welfare, the decade of the 1970s and after witnessed the impacts of global oil shocks, supply-side economic policies, and deindustrialization in America, which aggravated the distribution of income.

\section{Slicing of the Economy's Pie : Class Attributes}

There are essentially three ways in which the economic strata in American society can be grouped: namely, on the basis of the distinction between labor and capital ; by the level of education and skills ; and by gender, race and ethnicity.

\section{A. Labor v. Capital}

While per capita income in the United States has been steadily rising, real wages, as shown in Figure 4, have been falling about a half percentage point a year since the mid1970s. This declining trend reverses the preceding pattern. Real wages fell more drastically after 1988, and continued to lose ground in the 1990s, standing in 1995 about 3\% below where they were in $1989^{5}$. In 1994 the median family income after adjusting for inflation was $\$ 39,881$ compared to $\$ 42,049$ in $1989^{6}$.

The losing grounds of the worker have been offset by the gains by wealth holders in America. The income of the very rich is
Figure 2 Trends in US Income Distribution : 1979-1993 (Gini coefticient)

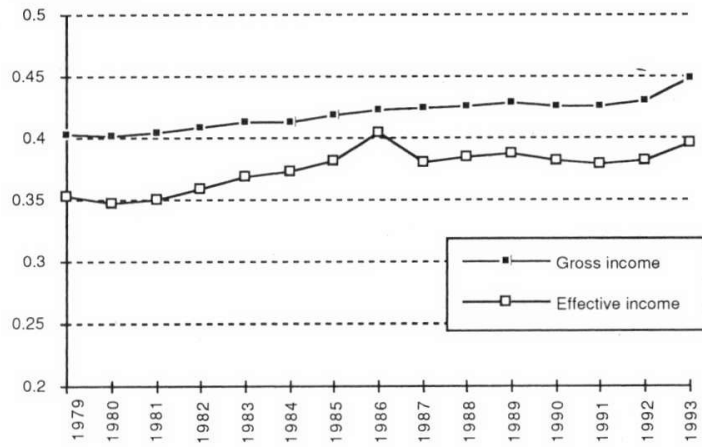

Note: Gross income is total money income, excluding capital gains. Effective income is money income after taxes and transfers, including capital gain.

Source:U. S. Bureau of the Census; "Index of Income Concentration tables, Cols. 3 \& 15."

largely accounted for by nonwage sources. According to a recent study ${ }^{7}$, only one-half of $1 \%$ of the US population (half a million US households) currently own $39.3 \%$ of all assets (stocks, bonds, cash, life-insurance policies, paintings, jewelery, etc. ${ }^{8}$. This makes the United States No. 1 among the industrialized nations in inequality. During the Reagan years of 1983 to 1989 , the nation's net worth rose from $\$ 13.5$ trillion to $\$ 20.2$ trillion, and $\$ 3.9$ trillion of the gain was captured by the top one-half of $1 \%$. That worked out to a $\$ 3.9$ million bonanza per wealthy household ${ }^{9}$. 
Figure 3. Trends in Poverty Incidence : 1959-93

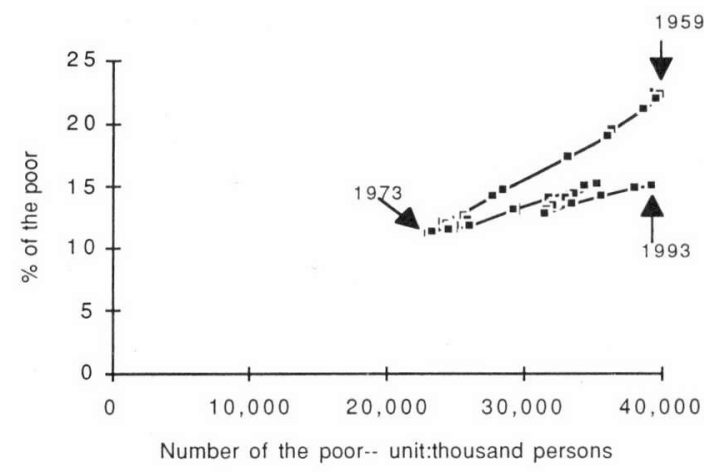

Source:U. S. Bureau of the Census, "Income and Poverty 1993."

Figure 4. Hourly Real Wages, 1965-93

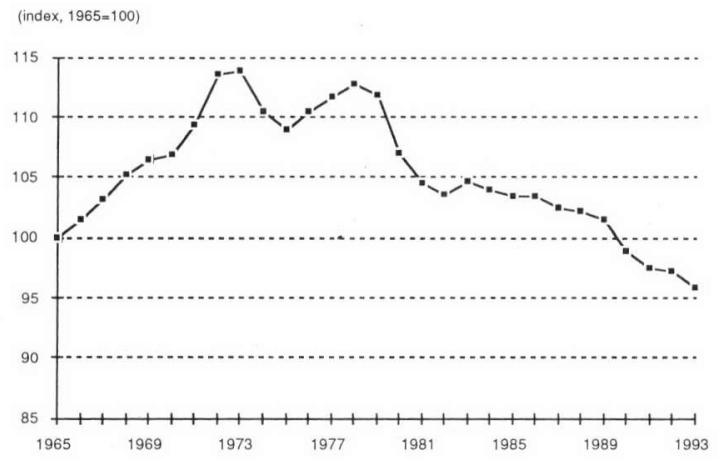

Source: J. E. Stiglitz, Economics (1993, data diskette).

In this context, profits at major American corporations surged. According to a Wall Street Journal survey ${ }^{10)}$, net profit income at 674 major companies rose a cumulative 48\% during 1994. In the 1994 fourth quarter alone, net income increased $61 \%$ from a year earlier. Increased net profits, rather than a result of greater investment, have been fuelled by a trend set in the early 1980s that allows companies to retain more of their profits after taxes. The percentage of corporate income paid in taxes fell from an average of $44.3 \%$ in the 25-year period that ended in 1979 to 32.4 $\%$ in the 1980 s and to $31 \%$ in 1994 . Also, behind the strong gains in the recent past is evidence that companies found new ways to reduce their costs, especially labor costs, while passing along higher raw-material prices to customers. For example, the costs of employee benefits-everything from health insurance to retirement plans-rose just $0.2 \%$ in the first quarter of 1995, the slowest rate of growth in eight years. The stagnant earnings of rank-and-file employees provide a sharp contrast to the wealth accumulation of American owners of capital. Recent years have seen a dramatic rise in the relative as well as the absolute level of compensation for chief executive officers of large corporations. They received compensations, mostly in the form of options to purchase company stock under favorable terms, that was 149 times and 212 times, respectively in 1993 and in 1995, as much as an average American worker. Back in 1960, their compensation was only 40 times higher than workers. In Japan, the heads of major corporations earned only 32 times more than their workers ${ }^{11}$.

\section{B. Skilled v. Unskilled}

The widening gap in American income is also discernible in the distribution of wages and salaries among its work force. The figures for real wages in Figure 5 pertain to the unskilled labor group consisting of production and nonsupervisory workers, who cover about two thirds of the total work force. The share of income paid for production and nonsupervisory work has been falling in recent years while the share going to white-collar workers including professionals, supervisors, managers and owners has been rising. Figure 5 shows that from 1968 to 1994 the top $20 \%$ of all working households saw their annual inflation-adjusted salaries and salaries grow by a whopping $44 \%$ as compared to just $8 \%$ by the bottom $20 \%$. The middle $60 \%$, however, saw the share of their incomes shrinking from 53\% in 1968 to $47.3 \%$ in 1994. Although the widening wage gap has been a phenomenon that started since the late 1960 s, it accelerated in the past several years. For instance, from 1992 to 1994 the income share of the top 5\% wage income bracket went up by almost $14 \%$.

The widening wage gap has largely resulted from rapid changes in technology and the globalization of an economy that began to show very little use for people without much education and training. Nonetheless, the contrast in impacts in the United States relative to other Western European countries is strik- 
Figure 5. Shares of Wage and Salary Eamings by Income Classes

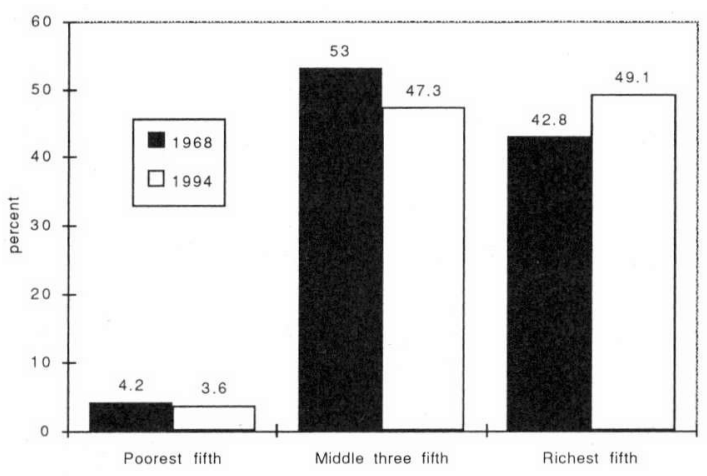

Source: U. S. Bureau of the Census 1994.

ing: For instance, in Germany the high-wage earners make about two and a half times as much as the low-wage workers; the gap has been narrowing in Germany. In the United States the figure is above four times with the disparity rising; during the 1980 s, far more jobs in the low-paid-unskilled category have been created in the United States than in Western Europe ${ }^{12)}$.

The wage gap in the American economy mirrors the differences in the level of education. While the income gap between high-and low-skilled workers in America is shown to have doubled during the 1980's, the workers reaping most of the economic gains have been those at the higher end of the education spectrum with the biggest losers being those who did not go beyond high school, particularly for the men. For instance, in $1992 \mathrm{col}$ lege graduates made an average of $82 \%$ more than high school graduates, up from only $43 \%$ in 1972 (Table 1). The really big returns to education these days come with advanced degrees - Ph. Ds, MDs, JDs, CPAs and so on. In 1972, people with advanced degrees earned $72 \%$ more income than high school graduates. By 1992, they made 2.5 times more. High school dropouts now earn scarcely half as much as high school graduates, and the gap has been widening. Those with less than college education have been the only group that has less real income to spend now than they did in 1970. The income premium to education has become substantial and has grown markedly over the past two decades ${ }^{13)}$.

Table 2 compares the unemployment and
Table 1: Index of Income By Educational Attainment,1972 and 1992

(Index, high school $=1.0$ )

\begin{tabular}{lcc}
\hline & $\underline{1972}$ & $\underline{1992}$ \\
Dropout & .60 & 1.0 \\
High school graduate & 1.0 & 1.25 \\
Some college & 1.10 & 1.82 \\
College graduate & 1.43 & 2.54 \\
Advanced degree & 1.72 & \\
\hline
\end{tabular}

Source: Cox and Fox (1995, p. 5).

poverty rates by the level of education. In 1991 while almost half of the sampled workers had some education past high school, 13.3\% did not receive a high school diploma. The consequences of not gaining a high school education appeared quite serious ; 24.7 $\%$ of these workers failed to earn enough to raise their families out of poverty. Their unemployment rate was almost twice that of other workers.

\section{Social Stratification in Work Force}

Race continues to be an important factor in the ethnically heterogeneous American society. Individuals who hold this perspective point to the consistency by which blacks and members of other minority groups are disproportionately poor, undereducated, and without jobs. Racial preferences that exclude minorities from opportunities in society are seen as serving as a basis for this perspective.

As shown in Figure 1, inequality by race and Hispanic origin, which has always been high, has further increased in the past two decades. In 1970, white households had average incomes $53 \%$ greater than black households. By 1992 this difference had risen to 60 $\%$, while whites had incomes $40 \%$ greater than Hispanics. From 1970 to 1992 white incomes rose $16 \%$, while Afro-American incomes rose only $11 \%$. In terms of poverty incidence, there has been no significant deviation by races over the period; the poverty rates fluctuated more or less in the same directions for the three racial groups (Figure 6). The poverty incidence for AfroAmericans and Hispanic Origin remained persistently at the rates more than twice that of whites: between 1992 and 1993 the poverty rate for whites was $12.2 \%$, for blacks $33.1 \%$, for persons of Hispanic origin 30.6\%, and for Asians and Pacific Islanders 15.3\%.

The income disparities by race are linked 
Table 2: Unemployment and Poverty Incidence by Level of Education

\begin{tabular}{lccc}
\hline & $\begin{array}{c}\text { \% of working } \\
\text { population }\end{array}$ & $\begin{array}{c}\text { Poverty } \\
\text { Rate } \\
(\%)\end{array}$ & $\begin{array}{c}\text { Unemployment } \\
\text { Rate(\%) }\end{array}$ \\
\hline $\begin{array}{l}\text { Less than } \\
\quad \text { High School }\end{array}$ & 13.3 & 24.7 & 7.8 \\
High School & 37.6 & 10.6 & 4.2 \\
College & 49.1 & 5.2 & 2.5 \\
Total & & 9.8 & 3.8 \\
\hline
\end{tabular}

Source: The Current Population Survey (March 1991). to aggregate wealth inequalities. In 1993, for example, the median net worth of all white households was $\$ 45,740$ compared to a mere $\$ 4418$ for black families ${ }^{14)}$. A recent survey reveals similarly substantial disparities in wealth among white and minority families ${ }^{15}$. In 1995 , while the top $5 \%$ of white retirees tapped more than $\$ 650,000$ per person in assets, some $40 \%$ of Hispanic households approaching retirement were found to have no private financial cushion at all. More disturbing is the fact that the distribution within the Afro-American group was far worse relative to other ethnic groups. The 1993 study shows that the ratio of the wealthiest quintile to the poorest quintile among black families was 180 compared to 7 for white families.

Similar to the ethnic disparities, the income gap between the genders also widened during the 1980, as shown by changes in the ratio of median female to median male earnings, which had remained stable over the 1970s. Increasing numbers of poor families are head- ed by a single female. According to the recent US Census data, as of 1995 about $46 \%$ of African-American families were headed by a single female, up almost by 6 percentage points since 1980 . This contrasts the 14\% figure for the white female-headed households in 1995, an increase by $2 \%$ since 1980 . Most of out-of-wedlock children live in single female headed households, and poverty in American society has been closely linked to singleparenthood, as shown in Figure 7.

Understanding poverty in American society must go beyond the three social classes discussed above. Who are the poor in American society? A recent Census Bureau survey estimated that over 36 million Americans lived below the poverty line in 1992. Females made up $65 \%$, or 23 million, of the poor. More than half of the poor females were whites, and about one third were black females. Many adult women who worked remained poor. In 1990 about $40 \%$ of the total population living in poverty worked full-or parttime jobs. While the public believes that poverty is primarily an urban issue, one sixth of all rural Americans live in poverty. But the greatest impact of poverty is among children. In 1994 more children under the age of 15close to 14 million - lived in poverty than in any year since 1965 . The poverty rate reached $22 \%$. The incidence of child poverty was particularly high among blacks and Hispanics; among blacks the poverty rate was $45 \%$; and for Hispanics $38 \%$, compared

Figure 6. Poverty Incidence by Race : 1973-93
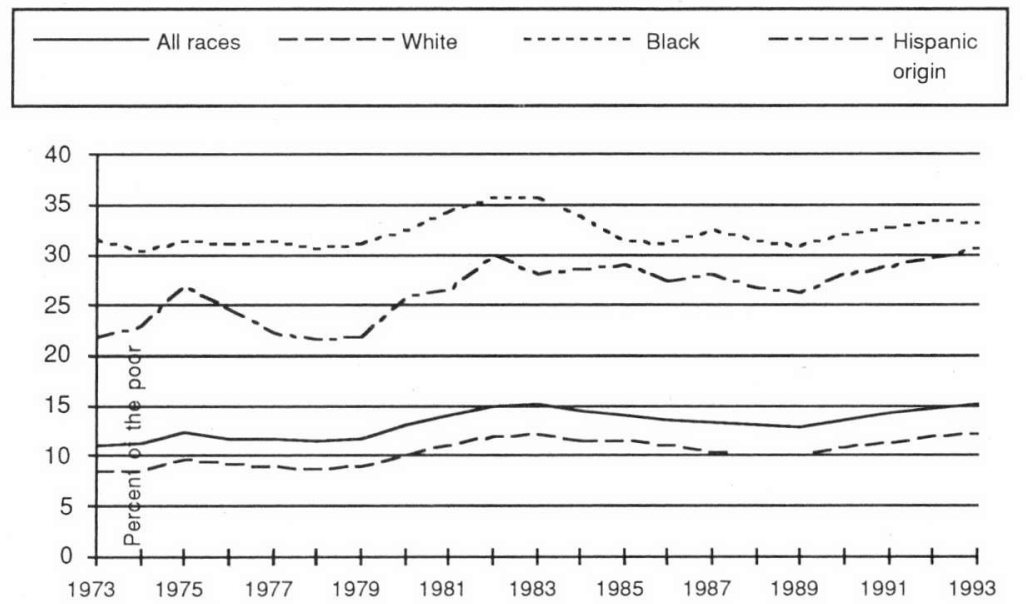

Source: U. S. Bureau of the Census, "Income and Poverty 1993." 
Figure 7. Poverty Incidence for Female-Headed Households

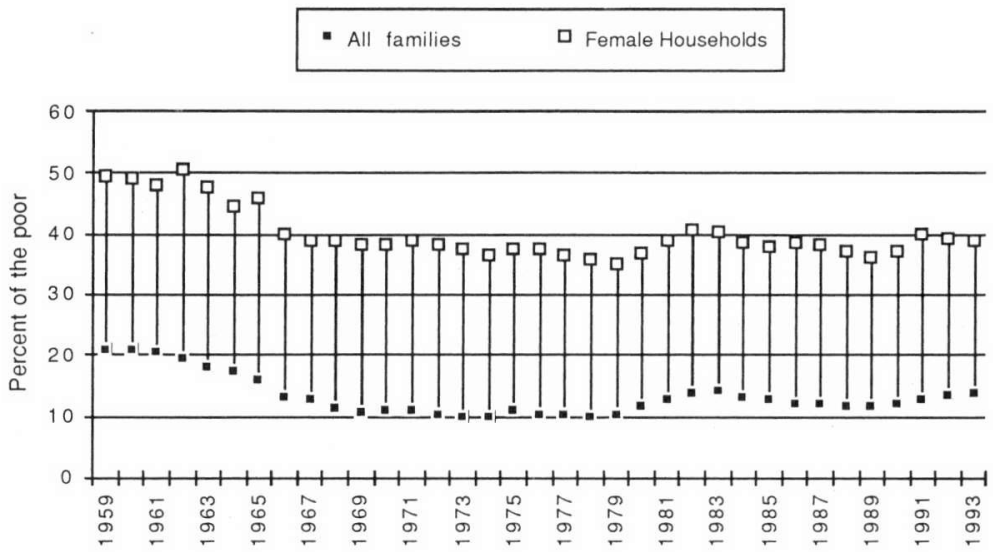

Source: U. S. Bureau of the Census, "Income and Poverty 1993."

to $16 \%$ for whites. The most invisible group living in poverty are the elderly. While the poverty rate among the elderly has declined since 1984, women over 65 comprise the largest group of elderly living in poverty.

\section{Sorting Out the Explanations for Inequality}

The previous section has examined the socioeconomic attributes of different income classes in the American economy. It will now be useful to review the explanations advanced in the recent literature on American inequality. This will enable us to assess its socioeconomic consequences in American society in a proper perspective and to better appreciate the range of policy possibilities for resolving the enduring social dilemma.

First of all, it must be understood that there is no single, definitive explanation for the growing inequality in America. The causes are indeed complex in nature as they involve the intricate dynamics of interactions among various social, economic and political factors. Based on the recent literature, a brief list of the leading arguments can be made from the perspectives of America's changing labor and capital markets, which are linked to the global economy. Finally, the continuing changes in the US. policy and institutional framework must be taken into consideration.

\section{A. Labor Market Segmentation Demand Side}

The argument here is that lack of both unskilled worker demand and adequate paying-job opportunities, which stems from the increasing globalization of the domestic economy, has been leading to rising inequality and poverty in America. The global economic integration is seen to adversely impact the distribution of income via shifting changes in the consumer demand profile in global markets: as the world income rises and the consumer demand for standardized products becomes saturated, the company's strategy shifts from the Fordist mass scale production of standardized products to more skill-intensive, quality-differentiated products. This results in the adoption of skillbiased technologies, causing the gradual shift in labor demand from unskilled to skilled, from higher wage manufacturing to lower wage services activities ${ }^{16)}$. For years, major American corporation have resorted to an alluring formula of downsizing and computerization, especially in the less-skilled, laborrequiring departments. While the conventional jobs in manufacturing, which have been a long standing place of employment for the unskilled and less educated, are diminishing, there have been increased demands for the better educated and more skilled workers. This has been a factor contributing to widened wage disparities. 


\section{Supply Side}

Turning to the supply side in the labor market, several economists reclining on the human capital theory consider the worker's education and experience as the essential factor contributing to wage disparities in the American economy. The changing patterns of differential returns to the human capital stock are seen to provide useful insights into the understanding of wage-income polarization. Bound and Johnson ${ }^{17)}$ thus argue that the dynamic changes in the relative supply of different types of workers have played an important role in determining the trends in earnings inequality in the American economy, and that growing wage disparities are linked to slower growth in the level and quality of education that match with the pace of the firm's requirements dictated by rapid technological changes.

From the perspective of aggregate labor supply, during the 19070s in the wake of the end of the Vietnam War and the military draft, there was a rapid increase of college graduates into the labor force. The massive entrance into the labor force of the cohorts of the 1970s, who were the members of the America's Baby Boom, however, led to reductions in their wages relative to older workers. The decade of the 1980s saw a different pattern in labor supply shifts. With the declining college premiums, many young persons who stemmed from the Baby-Bust generation decided to forgo a college education, which has led to a sharp decline in the growth of college educated workers. Increases in immigration and changes in the immigration laws in the 80 s also contributed to the declining "quality" of the work force. These factors led to a "softening" of labor markets in the unskilled category. The consequencies of a softened market has been partly reflected by changes in real wages of high school graduates and dropouts, which plummeted down by $12.7 \%$ and $18.7 \%$, respectively, during the $1980 \mathrm{~s}^{18)}$.

Another factor to consider is the aging population in America. Falling birth rates and longer life expectancy have been the causes of a graying population. In 1950, the over-65 population was fairly small, accounting for 8.1\% of all Americans. By 1990, its percentage went up to $12 \%$, and is projected to reach a peak close to $20 \%$ by 2040 , when the Baby Boom generation will be dying off ${ }^{19)}$. The longer-term implications for the distribution can be significant. There will be a growing strain on social security systems and government pension programs, which will increase the tax burden on the younger workers. Add to this, the increased burdens on national health systems and reduced incomes for the retirees are bound to affect the overall distribution of income.

\section{B. Globalization of Domestic Capital}

Another aspect of globalization in causing a widening gap between labor and capital relates to increased international competition facing domestic exports, internationalization of domestic capital, and outsourcing of domestic production. Many American corporations have responded to increased global competition and the consequent downward pressure on their profits by accessing to lowwage labor pools abroad, forcing down domestic wages $^{20)}$. In an increasingly globalized, information-and service-oriented economy, traditional manufacturing and metal industries have been hard hit. During the period of de-industrialization throughout the 1980 s, the US. experienced a decline in the demand for American exports. To reverse declining profits, management in one industry after another employed strategies aimed at lowering the production costs by reducing demands also for high-wage "semi-skilled" labor.

Many firms adopted new technologies, which made only highly skilled workers more productive, and opted at the same time to farm out the production to abroad, leaving only management and financial jobs in the United States ${ }^{21)}$. In a recent survey ${ }^{22)}$, about $86 \%$ of major American corporations currently outsource some services, a jump from $58 \%$ in 1992 . The outsourcing has varied in method but entailed deindustrialization in some key sectors of the economy with severe impacts on employment. As transnational capital mobility continued to ease ${ }^{23)}$, business capital began to encompass not just physical plant and machinery but more and more of intellectual capital as well. What is left has been the growing concentration of employment in both the high wage professional 
occupations and low-wage service industries a polarization of jobs and earnings ${ }^{24)}$.

\section{Policy and Institutions}

The final explanation relates to changes in the institutional structure of labor markets, particularly the decline in unionization and the slide in the real value of the minimum wage $^{25)}$. Union membership in America has declined drastically in recent years as many thousands of union members have lost jobs from restructuring and downsizing of the corporations. Unions now represent some 15 $\%$ of all workers, down from a high of $39 \%$ in the 1960s. American unions do not have much leverage vis-àvis management in negotiating contracts and organizing workers.

Another factor contributing to low equality has to do with the politics of poverty. Persistence of poverty in American society derives from the lack of political power of the poor predominantly represented by the racial and ethnic minorities, single female parents and children. In a political democracy, those with resources to invest in the political process exert a disproportionate influence as they can organize lobbying efforts that sustain political pressure on legislators. The well-to-do in society have been able to create a political economy that gives them an edge over the rest. Evidence of this is revealed by the regressive impacts of many government programs.

For instance, the average recipient from Federal entitlements ${ }^{26)}$, which accounted for more than a half of all federal outlays in 1990, collected $\$ 10,320$ as benefits in the same year. As shown in Table 3, however, the payments are larger as one moves up on the income scale. This is America's 'wealthfare' system : Federal governments spent $\$ 177$ billion on entitlements for the poor in 1994 but spent $\$ 612$ billion on entitlements for everyone else. In the largest retirement program of Social Security, while the average recipient obtained $\$ 7,880$ in 1990 , those with incomes between $\$ 50,000$ and $\$ 75,000$ received $\$ 9,300$, and those with incomes over $\$ 150,000$ an average of $\$ 10,170^{27)}$. The farm subsidies were another set of entitlements which more heavily benefited better-to-do. A study shows that during the early 1980 s the farmers earning $\$ 100,000$ or more received about 60 per
Table 3: Government Entitlements by Income Groups

\begin{tabular}{ccc}
\hline $\begin{array}{c}\text { Family income } \\
(1990 \text { dollars) }\end{array}$ & $\begin{array}{c}\% \text { of all families } \\
\text { receiving benefits }\end{array}$ & $\begin{array}{c}\text { Average benefits per } \\
\text { recipient family } \\
(1990 \text { dollars) }\end{array}$ \\
\hline All families & 49 & 10,320 \\
$\$ 1-\$ 9,999$ & 71 & 7,880 \\
$\$ 10,000-\$ 19,999$ & 57 & 10,340 \\
$\$ 20,000-\$ 29,999$ & 46 & 11,220 \\
$\$ 30,000-\$ 39,999$ & 41 & 11,350 \\
$\$ 40,000-\$ 49,999$ & 36 & 11,460 \\
$\$ 50,000-\$ 74,999$ & 34 & 11,910 \\
$\$ 75,000-\$ 99,999$ & 35 & 13,060 \\
$\$ 100,000-\$ 149,999$ & 32 & 14,640 \\
$\$ 150,000$ or more & 9 & 16,190 \\
\hline
\end{tabular}

Source: Congressional Budget Office; Joint Committee on Taxation.

cent of their income from direct government payments, rents, and dividends ${ }^{28)}$. The corresponding figure for farmers with incomes of less than $\$ 5000$ was a mere $6.9 \%$.

\section{Toward A Grand Synthesis}

The previous section has been devoted to the examination of various hypotheses explaining the causes of changing distribution in the American economy. Nonetheless, the overall picture piecing together the building blocks has not been attempted. In Figure 8, a synthesis of previous discussions is made by illustrating the directions of influence among various factors on distribution and growth. The figure also shows the distributional implications of changes in America's social economy over the long run. Rising inequality is related not only to the changes in the economy that increasingly rewards the owners of capital and skills but also to the dynamic changes in social structure as affected by the breakdown of family system, demographic shifts in age cohorts, and/or changing composition of ethnic minorities. Exactly how these social changes will interact with one another and with other economic factors is not analyzed here.

\section{Socioeconomic Consequences of Inequality}

Inequality and poverty reflect a set of conditions that affect the quality of life. The implications, however, are far-reaching to the social economy, certainly going beyond the individuals affected. This section looks into such consequences in the context of 
Figure 8. A Schematic View of Growing Inequality in the U. S.

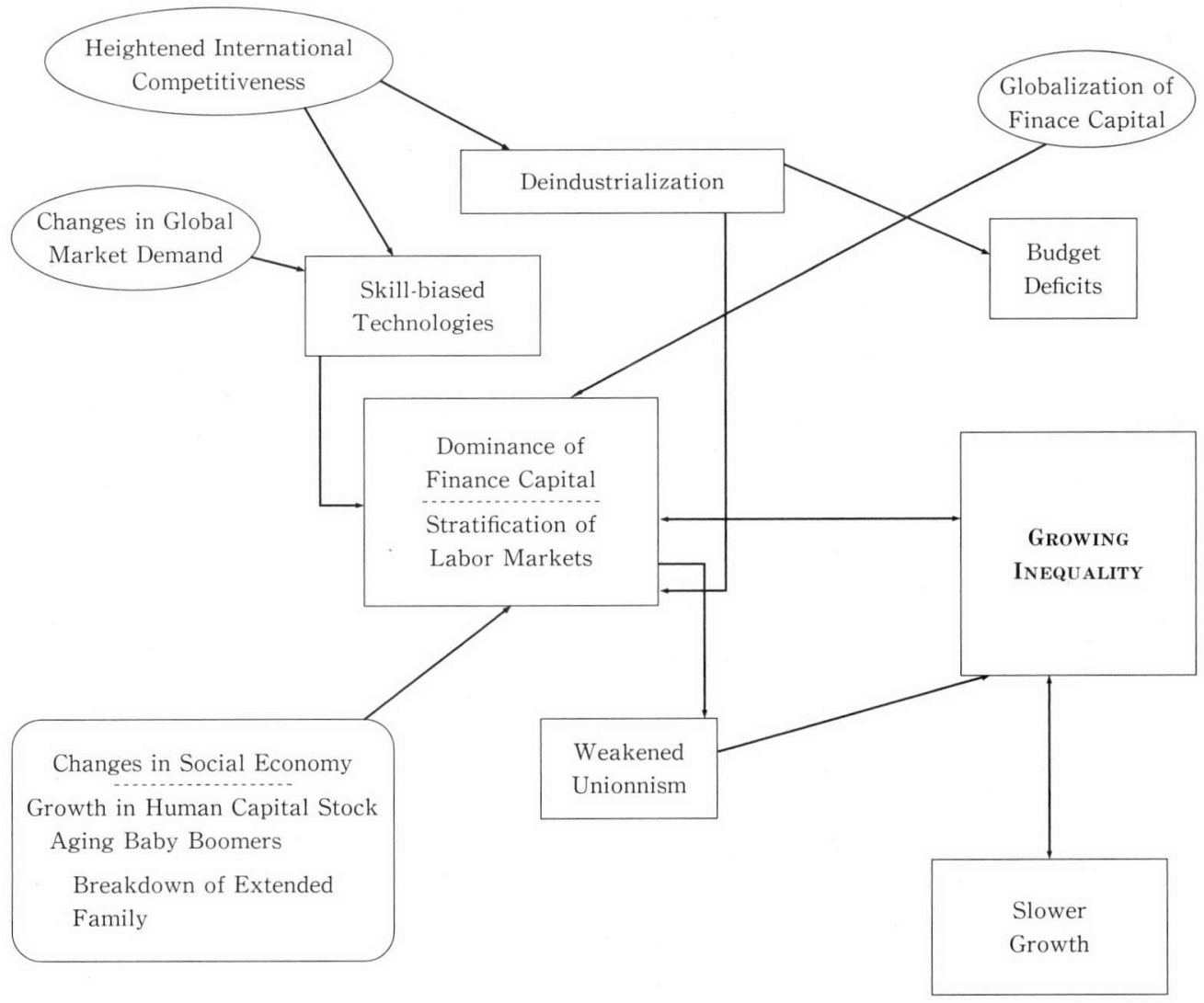

America's social economy.

\section{A. Social Sectors}

Three most significant social sectors in American society affected by inequalities are children, and education and health of the poor. First, every fifth child in America lives in poverty, and the children raised in poverty are three times more likely to die before reaching their adulthood. The widely publicized Luxembourg Income Study ${ }^{29)}$ reports that the child poverty rate in the United States in 1991 was $21.5 \%$, highest in the industrialized world and almost a third higher than the second highest country-Australia. Part of the blame for the child poverty falls on the inadequacy of American governments' antipoverty programs. Although the incidence of child poverty in America was reduced by a margin of $4.4 \%$, other governments did much better. In Sweden, for example, as a result of government intervention the child poverty rate fell from $19.1 \%$ to $2.7 \%$; and in the
United Kingdom from $29.6 \%$ to $9.9 \%$. America's well-to-do children are richer than the counterparts of any other nation. But its poor children have less to live on than those in other industrialized nations. Most of these countries would have double-digit child poverty rates-like America's-were it not for their government policies that lifted millions out of poverty ${ }^{30)}$.

Second, income and human capital are related to each other, in particular at the lower level. As noted already (Table 1), educational attainment is closely correlated to income levels in the United States. Individuals earning low incomes have limited opportunities for better education and training, and therefore limited access to better-paying jobs. The vicious cycle is complete for most of the working poor in America.

Third, because of the difficulty in measuring health status the impact studies on health have generally been concerned with mortality rates. In the postwar era, the mortality rates 
have fallen sharply throughout the developed world, and life expectancy has increased dramatically. Although overall mortality has decreased in most countries including the United States, individuals of lower economic status have higher mortality rates than those of higher status. This is largely because the poor in America have virtually no access to quality health care as low income restricts their choice of physician, health care plan, and treatment option. A number of studies have shown evidence of differential mortality by socioeconomic status in America ${ }^{31}$. Kitagawa and Hauser's study ${ }^{32}$, based on the Chicago area data over the period of 1930 and 1960, revealed a negative relationship between income levels and mortality: for both genders and all age groups, the lowest income group had a mortality rate that was more than $50 \%$ higher than the rate of the highest. In a different context, Silver, Feldman and his colleagues ${ }^{33}$ confirmed the robust effects of education on mortality. Their study which targeted an older population (over 65 years) found that over the period of 1971-84 the mortality of the least educated (0 to 7 years), who were concentrated in the lowest income class, was nearly twice that of the more educated (13 or more years). Others ${ }^{34}$ similarly showed that health-related mortality rates are higher in poorer areas, where basic health services are substandard, and that the housing conditions in a poverty area are as important a determinant of high mortality as other factors. Focusing on the link between social classes and heart disease mortality, the lower-middle groups were found to have about twice the mortality rate of the upper-middle, and the working poor had more than four times the mortality of the upper-middle ${ }^{35)}$.

\section{B. Violence in Society}

Rising inequality and poverty in America throughout the 1980s have prompted damaging changes in the nation's economic and social fabric. The uneven impacts of economic changes have not been limited to the working poor but also fallen on middle America; job displacement in relatively well-paid blue-and white-collar occupations became prevalent, resulting in the growing number of the homeless on city streets, economic crimes, and social unrest. Racial minorities, in particular, the blacks and those of Hispanics origin, were especially hard-hit by technological changes.

Table 4 indicates that the crime rate ${ }^{36)}$ rose nearly 10\% over the period of 1983 and 1992 . Comparisons with the 1963 figure show that the crime rate almost doubled over the past three decades. For all Americans, the odds of becoming a victim were far greater in 1992 than they were in 1963 when the crime index reached 2,180 crimes per 100,000 people ${ }^{37}$. In 1992, police agencies reported investigating 5,668.2 crimes per 100,000 people. Property crime has been the most prevalent form of criminality $^{38)}$. Also, violent crimes and violence tend to be higher in areas that are more densely populated by lower-income, racial minorities, as in the case of the 1992 racial riot in Los Angeles, or in areas characterized by greater residential instability. It is well to note that a large portion of violent crimes included robberies which can be considered to spring from economic causes. Also, the material disadvantage in a poverty area can be seen as raising levels of community violence. The sheer lack of adequate resources in a poverty area precludes possibilities of developing any effective community-based mechanisms of social control.

Patterson $^{39)}$ examined the statistical relationship of inequality and poverty to criminal activities, controlling for influences of poverty areas. His results show that levels of absolute poverty in an area are significantly associated with higher rates of violent crime related to economic incentives. In a study based on the cross-sectional data from 127 metropolitan areas in the United States, Lee $^{40)}$ observed a positive correlation between property crime and income inequality. Based on an analysis of the trends in crimes in 28 cities for the period from 1975 to 1990, Mishel and Bernstein ${ }^{41}$ also found a statistically significant positive correlation between poverty and unemployment on one hand, and crime rates on the other. For instance, the rise in poverty in America was found responsible for $5 \%$ of the increase in both homicides and burglaries between 1989 and 1990. The United States has also an extraordinarily high proportion of incarcerated population of working age. In 1993 the 
Table 4: Crime in the US., 1973-92

(Rate per 100,000 inhabitants)

\begin{tabular}{|c|c|c|c|}
\hline & Crime index total & Violent crime ${ }^{\mathrm{a}}$ & Property crime ${ }^{b}$ \\
\hline 1992 & $5,660.2$ & 757.5 & $4,902.7$ \\
\hline \multicolumn{4}{|l|}{$\%$ change } \\
\hline $1992 / 1988$ & $\begin{array}{l}-0.1 \\
(+3.7)^{\mathrm{c}}\end{array}$ & $\begin{array}{c}+18.9 \\
(+23.4)\end{array}$ & $\begin{array}{l}-2.5 \\
(+1.2)\end{array}$ \\
\hline $1992 / 1983$ & $\begin{array}{c}+9.4 \\
(+19.2)\end{array}$ & $\begin{array}{c}+40.9 \\
(+53.6)\end{array}$ & $\begin{array}{c}+5.7 \\
(+15.3)\end{array}$ \\
\hline
\end{tabular}

Notes: a. Violent crimes are murder, rape, robbery, and aggravated assault.

b. Property crimes are burglary, larceny-theft, and motor vehicle theft.

c. Figures in parentheses are percentage change in actual frequencies

Source: FBI : 1992 Uniform Crime Report.

number incarcerated was $1.9 \%$ of the male work force; and among blacks, was $8.8 \%$ of the work force. But for the massive imprisonment, the crime rates would have been much higher.

There are certainly other social and cultural factors contributing to high crime rates in American society: communities with diverse ethnic origins, as in America, are likely to have more internal conflicts than culturally and ethnically homogenous societies. Also, in American communities such traditional institutions as family, school and local community appear less able to exert social control over the behaviour of community members. Nonetheless, the fact that crime rates, particularly economic related crimes, tend to rise during the period of rising inequality reveals that both absolute and relative deprivations are important determinants of violence in society.

\section{Inequality and Growth}

Economists have long disagreed on their views on the link between income distribution and economic growth ${ }^{42}$. The earlier supplysiders and more recent Neoliberal economists have argued that current inequity must be endured for the sake of future growth and equity since the benefits of growth would eventually filter down to the masses. In this context, redistributive policies would be seen as reducing the incentives for work and investment, thereby adversely affecting the overall efficiency of the economy.

Empirical evidence, nonetheless, has not been conclusive in supporting the trade-off or the-rising-tide-lifting-all-boats theory. A num- ber of mature industrial economies in the past decade saw income inequality rising during economic expansions as well as contractions. For instance, during 1989-92 the expansion of industrial production in those countries (in particular, Sweden, Finland, the USA, the Benelux countries, England, etc.) has been accompanied by rising unemployment, which further reduced income equality. The lesson is simple: economic expansion does not necessarily engender equity.

Turning to the trade-off between equity and efficiency, the recent, cross-sectional study by Glyn and Miliband ${ }^{43)}$, which includes a large number of both industrial and developing countries, indicates a positive correlation between the countries with more income equality and those with higher growth rates. During the 1980s, countries with relatively faster labor productivity growth, such as Japan, Finland, Germany, the Netherlands, Belgium and Sweden, were more equal in income distribution (as measured by the ratio of income of the richest $20 \%$ of the population to the poorest $20 \%$ ). On the other hand, countries with slower productivity growth, such as New Zealand, Australia, Switzerland and the United States, were relatively less equal.

Thus, income equality appears to have played a significant role in setting those countries on the path toward stable growth. Recent international data indicate that those countries with low inequality have been the same ones with high productivity gains. A similar result was confirmed by T. Persson and $\mathrm{G}$. Tabellini based on the data from industrial democracies ${ }^{44)}$, in which they discerned a negative correlation of inequality to subsequent growth ${ }^{45}$.

If the conventional theory relating distribution to growth is to be debunked, how do we then explain the positive growth effects of increased equality? The economists leaning toward Keynesian economics would look at the role of aggregate demand in a market economy, and deduce the positive effects of increased equity on demand and economic growth $^{46)}$. Other economists, as already noted, have related increased equality to increased access to health care, training and education for the population at large, which in the long term should raise worker produc- 
tivity and improve performance of the economy.

Another reason that inequality hampers growth relates to the economic costs of inequality on productivity. Persson and Tabellini argue that in a society with a widening income gap, redistributive policies likely result in taxing investment and growthpromoting activities. For a different reason also, redistribution is economically costly if a baseline of support must be provided for the welfare, health care, education and training of its populace. Growing inequality also leads to increased expenses of enforcing the law and order to protect the property rights and market system. As the 'haves' possess more to protect and the 'have-nots' less to lose and less prospects for a better future through work, crime goes up. In a highly unequal American society, the growing number of the incarcerated population exacts enormous costs for upkeeping the prisons, which also reflects a monumental loss of human resources ${ }^{47)}$.

\section{Conclusion}

Growing inequality in America in recent years is reflected by a widening income gap between capital and labor and between better educated and less educated. Low equality has also been associated with the relative decline of middle class America and an increasing incidence of poverty. The more disturbing fact is that income inequality - already vast in the United States — has grown much faster here than anywhere else in the West. The main point of this paper is that policies that increase the disparity between the wellto-do and the dispossessed will not just hurt the obvious victims; almost everyone will be better off if economic resources are distributed more equally. It is argued that economic growth with certain distributional equity must be seen as a moral as well as an economic imperative in a market economy.

The imminent task facing the contemporary American economy is to define and implement an alternative path for economic growth in which the safeguarding of some minimum economic equity is consistent with the market economy's operations. The challenge is how America's prevailing ethos founded on the concept of inviolability of the individual's free will could be readjusted in the light of the devastating present and prospective social consequences of rising inequality.

(Kellogg Institute for International Studies \& Department of Economics, University of Notre Dame)

\section{Notes}

1) Between 1974 and 1993 median household income fell about a tenth of a percentage point annually. US household income statistics today significantly underestimates the true income gains of an average American as the current household size is much smaller than yesterday's (2.63 today versus 3.01 persons in 1973).

2) Cox and Fox, 1995.

3) Wolff, 1994.

4) Kosters and Ross, 1988.

5) Michel, Bernstein and Schmitt, 1995.

6) The recent increase in the minimum wage should somewhat improve the situation, but since most of lower wage earners already make more than the mimum level, this may not affect the pattern of distribution significantly.

7) Wolff, 1995.

8) The US figure for the richest $1 \%$ is twice as much as that in Britain, which is considered as the most unequal country in Western Europe.

9) According to Wolff (1995), the last time the national asset were so unevenly distributed was in 1929 just before the stock-market crash.

10) May 1, 1995.

11) Folbre 1995.

12) Harrison and Bluestone, 1988; and Levy and Murnane, 1992.

13) More recently, even many college graduates are not doing well. Only those at the very top of the wage-earning scale are making progress.

14) Business Week, November 6, 1995.

15) Rand Corp. 1995. "Wealth and Savings." a survey report. Santa Monica, CA. December.

16) Harrison and Bluestone, 1988: op. cit.

17) Bound, J. and G. Johnson. 1989.

18) See Michel, L. \& J. Bernstein, 1994. The 1995 U. S. Census figures, however, show that far more Americans-both blacks and whites-completed high school, and slightly more finishing college. College graduates still account for $24 \%$ for whites and $13 \%$ for blacks in 1995 . There is no clear evidence as yet that the labor market has begun a longer-term "tightening" cycle.

19) Paris: OECD, World Almanac 1995.

20) Harrison and Bluestone, 1988 : op. cit. 
21) Bluestone, B. and B. Harrison. 1982. and Katz. L. and K. Murphy (1992).

22) Business Week, April 1, 1996. pp. 26-8.

23) Murphy, Kevin, and Finis Welch (1992).

24) In a different context, Norwood (1987) argues that these trends in inequality simply reflect the effects of the business cycle. The implication of the argument is fairly benign as any apparent increase in inequality will be reversed with modest increases in overall economic growth. The recent experience in the American economy does not, however, support the argument of the cyclical effects.

25) Blackburn, Bloom, and Freeman; 1990.

26) Entitlements are the benefits from the government the citlzens are "entitled" to collect if they meet certain demographic or income definitions.

27) This is because social security benefits are based on a recipient's pre-retirement earnings and tax contributions.

28) North and Miller, 1983. p. 211.

29) For a summary report, see US News and World Report, March 16, 1996.

30) In contrast, poverty among America's aged population was a problem until 1970 but was markedly reduced through expanded social security programs and increased efforts to save by the aged.

31) For example; Silver, 1972 ; Kitagawa and Hauser, 1973 ; Fuchs, 1986 ; Feinstein, 1993 ; and Feldman, Makus, Kleinman, and Cornoni-Huntley, 1989.

32) See footnote 31 .

33) Among younger people, the mortality rate of the least educated was about twice that ofthe best educated in the United States during the 1971 -84 period. Footnotes 29 and 31.

34) Haan, Kaplan, and Camacho, 1987.

35) Many of these studies have methodological drawbacks because of the absence of data on other intervening variables affecting mortality. The examples of such missing variables are a person's behavioral characteristics, occupation, family upbringing, or health expenditures, etc. It is significant, nonetheless, that most of the empirical studies are consistent in indicating the significance of income and wealth, education, poverty all related to income inequality-as the primary determinant of mortality

36) The US case contrasts that of a more equal country like Japan. Comparative data reveal that Japan has one of the lowest crime rates in the industrialized world. The crime rate for 1975-measured as the frequency of crime per 100,000 inhabitants-was 5,282 in America as against 1101 in Japan, 4,721 in West Germany, and 4,282 in England. Ministry of Justice, Japan: Hanzai hakusho
(Annual, 1977)

37) The Time, January 30, 1995.

38) More recent FBI's figures show a decline in reported crimes. In the first half of 1995 compared to the same period of 1994 , there was a $1 \%$ decrease in overall reported crimes and a 5\% drop in violent crimes alone. This decline was attributed to increased employment opportunies, maturing drug markets, aging baby boomers, more arrests and prison sentences. Property crime, however, remained unchanged, which appeared more closely related to the failure to reduce poverty.

39) Patterson, 1991

40) Lee, 1993.

41) 1994, Table 1.37

42) For discussions on the American case in a postwar historical perspective, see Katz \& Murphy (1992), Wolff (1995), and Bluestone \& Harrison (1982).

43) Glyn and Miliband, 1994.

44) Persson and Tabellini, 1994.

45) A negative correlation between income inequality and growth is also discerned in the context of the domestic economy. A study by Ledebus for 85 American cities showed that cities with high levels of urban/suburban inequality had lower growth rates in jobs and income (Albelda and Tilly, 1995).

46) Greater income equality leads to greater demand since the propensity to spend tends to be greater with low-income families.

47) The opportunity cost of enforcing the law can also be seen as a loss in productivity. For example, the money spent to hire additional security and police could be used to hire child care workers, allowing more parents to enter the labor force, providing children with access to improved early childhood education.

\section{References}

Abelda, R. and C. Tilly. 1995. "Unnecessary EvilWhy Inequality is Bad for Business," Real World Macro-a Macroeconomic Reader from Dollar and Sense, Worcester, MA : Saltus Press.

Bluestone, B. and B. Harrison. 1982. The Deindustrialization of America, New York: Basic Books

Blackburn, McKinley L., David E. Bloom, and Richard B. Freeman (1990). "The Declining Economic Position of Less Skilled Men." In Gary Burtless (ed.), A Future of Lousy Jobs? Washington, D. C.: The Brookings Institution.

Bluestone, Barry (1990a). "The Great U-Turn Revisited : Economic Restructuring, Jobs, and the Redistribution of Earnings." in J. D. Kasarda (ed.), Jobs, Earnings, and Employment Growth Policies in the United States. Boston: Kluwer Academic Publishers. 
Bluestone, Barry (1990b). "The Impact of Schooling and Industrial Restructuring on Recent Trends in Wage Inequality in the United States." American Economic Review: Papers and Proceedings, 80 (2), May, 303-7.

Bound, J. and G. Johnson. 1989. "Changes in the Structure of Wages during the 1980s : an Evaluation of Alternative Explanations." National Bureau of Economic Research Working Paper, No. 2983, May.

Breslow, Marc. 1995. "Inequality Ascendant," A1belda R. \& et al. ed., Real World Macro 12th Edition, Somerville, MA: Dollars and Sense Publishers. 30-31.

Cox, W. M. \& B. J. Fox. 1995. "What's Happening to America's Income?" Federal Reserve Bank of Southwest Economy, Issue 2, 3-6.

Feldman, J. J., D. M. Makus, J. C. Kleinman, \& J. Cornoni-Huntley, 1989, "National Trends in Educational Differentials in Mortality," American Journal of Epidemology, 129: 919-33.

Feinstein, J.S. 1993. "The Relationship between Socioeconomic Status and Health: A Review of the Literature," The Midlank Quarterly, 71 (2). 279-322.

Folbre, N. 1995. The New Field Guide to the US Economy, (New York: The New Press).

Fuchs, V.R. 1986, The Health Economy, Cambridge: Harvard University Press.

Glyn, A. and D. Miliband, 1994. Paying for Inequality: The Economic Cost of Social In justice, London : the Institute for Public Policy Research. Haan, M., G. A. Kaplan, and T. Camacho. 1987. "Poverty and Health; Prospective Evidence from the Alameda County Study," American Joumal of Epidemiology, 125 : 989-98.

Hage, D., D. Fischer \& R. F. Black. 1995. "America's Other Welfare State," US News and Word Report, April 10.

Harrison, Bennett, and Barry Bluestone (1988). The Great U-Turn. Corporate Restructuring and the Polarization of America. New York: Basic Books.

Harrison, Bennett, and Barry Bluestone (1990). "Wage Polarization in the US and the "Flexibility" Debate." Cambridge Journal of Economics, 14 (3), September, 351-73.

Henle, Peter (1972). Exploring the Distribution of Earned Income. Monthly Labor Review, 95 (12), 16-27.

Henle, Peter, and Paul Ryscavage (1980). "The Distribution of Earned Income among Men and Women, 1958-77." Monthly Labor Review, 103 (4), 3-10.

Hinojosa-Ojeda and Robinson (1992), "Labor Issues in North American Trade." in North American
Free Trade, edited by Lustig, Bosworth, and Lawrence, Brookings, Washington, D. C. 69-108.

Katz. L. and K. Murphy (1992), "Changes in Relative Wages, 1963-1986." Quarterly Journal of Economics, 107 (1). 35-78.

Kitagawa, E. M., and P. M. Hauser. 1973. Differential Mortality in the United States: A Study in Socioeconomic Epidemiology. Cambridge: Harvard University Press.

Kosters, M. H., and M. N. Ross (1987). The Distribution of Earnings and Employment Opportunities: a Re-examination of the Evidence. Washington, D. C.: American Enterprise Institute.

Kosters, M. H., and M. N. Ross (1988). The Quality of Jobs : Evidence from Distributions of Annual Earnings and Hourly Wages. Washington, D. C.: American Enterprise Institute.

Latour, J., V. Lopez, M. R., A. Nolasco, \& C. Alvare-Dardet. 1991. "Inequalities in Health in Intensive Care Patients," Journal of Clinical Epidemiology, 44 : 889-94.

Lawrence, Robert Z. (1984). "Sectoral Shifts and the Size of the Middle Class." The Brookings Review, 3 (I), 3-11.

Leamer, L. (1991), "Wage Effects of a U.S.Mexican Free Trade Agreement." A paper presented at a workshop at Brown University, October.

Lee, David Sang-Yoon, 1993. "An Empirical Investigation of the Economic Incentives for Criminal Behavior," Harvard University BA Thesis, March.

Levy, Frank, and Richard J. Murnane. 1992. “U. S. Earnings Levels and Earnings Inequality: A Review of Recent Trends and Proposed Explanations", Journal of Economic Literature, 30 (3). 1333-81.

Michel, L. \& J. Bernstein, 1994. The State of Working America 1994-95, Washington, D. C.: Economic Policy Institute.

Michel, L., J. Bernstein, \& J. Schmitt, 1995. The State of Working America 1995-96, Washington, D. C.: Economic Policy Institute.

Murphy, Kevin, and Finis Welch (1992). The Structure of Wages. Quarterly Journal of Economics, 107 (1), February, 215-226.

North, D. C. and R. L. Miller, 1983. The Economics of Public Issues, (NY: Harper and Row).

Patterson, E. B. (1991). "Poverty, Income Inequality, and Community Crime Rates," Criminology, 29 (4), 755-76.

Persson, T. and G. Tabellini, 1994. "Is Inequality Harmful for Growth?" American Economic Review, 84 (3). 600-21.

Rand Corp. 1995. "Wealth and Savings." a survey report. Santa Monica, CA. December. 
Silver, M. 1972. “An Econometric Analysis of Spatial Variations in Mortality Rates by Age and Sex." in V. Fuchs ed., Essays in the Economics of Health and Medical Care (New York: Columbia University Press). 161-227.

Stiglitz, J., 1993. Economics (New York: Norton). Data diskette.
Wolff, E. N., 1994. “Trends in Household Wealth in the United States, 1962-83 and 1983-89." Review of Income Wealth, 40 (2), 143-74.

Wolff, E. N., 1995. Top Heavy: A Study of the Increasing Inequality of Wealth in America (N. Y : Twentieth Century Fund Press). 